\title{
Tissue-specific distribution of pyruvate kinase isoforms improve the physiological plasticity of Northern krill, Meganyctiphanes norvegica
}

\author{
Markus Salomon*, Reinhard Saborowski \\ Biologische Anstalt Helgoland, Alfred Wegener Institute for Polar and Marine Research, PO-Box 180, 27483 Helgoland, Germany
}

Received 14 February 2005; received in revised form 7 October 2005; accepted 10 October 2005

\begin{abstract}
The Northern krill, Meganyctiphanes norvegica (Crustacea, Euphausiacea) is widely distributed in the northern and northeastern parts of the Atlantic Ocean where it faces rapid variations in water temperatures and food. We studied the physiological potential of krill to compensate for environmentally induced metabolic changes. Two isoforms of the glycolytic key enzyme pyruvate kinase (PKI and PKII, EC 2.7.1.40) were partly purified from M. norvegica by anion exchange chromatography. Specific activities and catalytic properties of each isoform were determined in whole body extracts as well as in selected organs and tissues of males and females. Both PK-isoenzymes differed slightly in their temperature profiles, their activation energy and their molecular weights. PKI showed a high affinity for the substrate PEP and was not affected by fructose-1.6-bisphosphate (FBP). In contrast, PKII showed low affinity for PEP but was strongly activated by FBP, up to 40-fold. The specific PK-activity of whole organisms was lower in females $\left(44.9 \pm 4.8 \mathrm{U} \cdot \mathrm{g}_{\mathrm{ww}}{ }^{-1}\right)$ than in males $\left(61.3 \pm 7.7 \mathrm{U} \cdot \mathrm{g}_{\mathrm{ww}}{ }^{-1}\right)$. In females PK II represented $20 \%$ of the total PK-activity while it was only $10 \%$ in males. Highest PK activities were present in the hearts, the eyes, pleopods and in the thoracopods. In the stomachs and the midgut glands PK activities were low. Almost all organs contained PKI and PKII. However, PKI prevailed in the abdomens, the pleopods, the thoracopods, and in the thoracic muscles. PKII dominated in the eyes, the midgut glands and in the ovaries. Experiments showed that the tissue concentrations of FBP increased with food uptake and temperature. The expression of two PK-isoforms with different kinetic properties and the mediation of substrate affinity by FPB is a powerful tool to immediately regulate glycolytic energy flows in different organs. The krill is capable of adjusting energy consumption to changes in nutritional conditions as well as variations of environmental temperatures.
\end{abstract}

(C) 2005 Elsevier B.V. All rights reserved.

Keywords: Fructose-1.6-bisphosphate; Isoenzymes; Meganyctiphanes norvegica; Nucelotides; Pyruvate kinase

\section{Introduction}

The Northern krill, Meganyctiphanes norvegica (M. Sars) (Crustacea: Euphausiacea) is an abundant plank-

\footnotetext{
* Corresponding author. Present address: Geschäftsstelle des Sachverständigenrates für Umweltfragen, Reichpietschufer 60, 10785 Berlin, Germany. Tel.: +49 30263696125.

E-mail address: markus.salomon@uba.de (M. Salomon).
}

tonic crustacean in the northeast Atlantic and adjacent seas (Mauchline, 1960; Mauchline and Fischer, 1969). It performs extended diurnal vertical migrations and has to spend substantial metabolic energy to remain pelagic (Kils, 1981; Tarling et al., 1998). Northern krill live at water temperatures from 2 to $16{ }^{\circ} \mathrm{C}$ and appear in high productive as well as in oligotrophic waters (Einarsson, 1945; Lindley, 1982). This way of life demands a high physiological flexibility towards var- 
iations of environmental temperatures as well as trophic conditions. Accordingly, a high potential of metabolic regulation must be expected in terms of energy flow, substrate turnover, and, thus, the performance of metabolic key enzymes.

We focused our interest on pyruvate kinase (PK, EC 2.7.1.40), a glycolytic key enzyme with high regulatory potential (Michaelidis and Storey, 1990; Oeschger and Storey, 1990; Bonamusa et al., 1992; Lazou and Frosinis, 1994). In mammals, at least three different isoenzymes of PK were identified. The type $\mathrm{M}$ isoenzyme appears in the skeletal muscle, the heart and the brain. It shows hyperbolic kinetic properties enabling high glycolytic turnover rates. Type $\mathrm{L}$ is present in tissues such as liver and kidney which carry out gluconeogenesis. This isoform shows cooperative substrate binding properties and is controlled by hormones. The third isoenzyme, type A, is located in most other tissues with intermediate glycolytic properties and is the predominant form during early development and in neoplastic tissues (Imamura and Tanaka, 1972; Imamura et al., 1972).

In crustaceans two distinct isoenzymes (PKI and PKII) were isolated. However, their tissue distribution and their detailed physiological roles are not sufficiently investigated yet (Lesicki, 1976; Guderley and Hochachka, 1977). Previous work on Northern krill showed that the activity of either isoenzyme was regulated differently. PKI did not respond to fructose-1.6bisphosphate (FBP) while PKII was directly affected by FBP (Salomon et al., 2000).

In order to study the roles of the pyruvate kinase isoenzymes in the regulation of metabolic performance in the Northern krill, M. norvegica, we investigated the properties, the distribution and the specific activities of both isoenzymes in different organs and tissues. Additionally we maintained krill in the laboratory at different temperatures with food and without food and measured the tissue concentrations of ATP and FBP, which are the major effectors of PK.

\section{Materials and methods}

\subsection{Origin of animals}

M. norvegica were captured with a multi-net (MOCNESS, Wiebe et al., 1985) in the Danish Kattegat $\left(57^{\circ} 16 \mathrm{~N}, 11^{\circ} 25 \mathrm{E}\right)$ during a cruise with the "FS Heincke" from 17 July to 7 August 1998. The hauls were kept short for 10-20 min to minimize damage of krill. Animals were sorted from the net. Krill were wrapped individually in aluminium foil and immediate- ly placed in a $-80{ }^{\circ} \mathrm{C}$ freezer. There the samples were stored until analysis.

Feeding experiments were carried out in Kristineberg Marine Research Station with animals from the Gullmarsfjord (Sweden, $58^{\circ} 20 \mathrm{~N}, 11^{\circ} 34 \mathrm{E}$ ) in late summer 1999 (20-27 September). Krill were caught with an Isaacs-Kidd Midwater Trawl (Isaacs and Kidd, 1953) from $90 \mathrm{~m}$ depth. The hauls lasted 5 to 10 min. The animals were immediately transferred into pre-cooled $\left(8{ }^{\circ} \mathrm{C}\right)$ sea water and shipped to the laboratories.

\subsection{Feeding experiments}

The effects of nutrition and temperature on the concentrations of ATP and FBP were studied in laboratory experiments. Individual krill were maintained for 6 days in 1-1 glass beakers in darkness. The experiments were run at 6 and $12{ }^{\circ} \mathrm{C}$. These temperatures were the same as in the deep water $\left(6^{\circ} \mathrm{C}\right)$ and the surface water $\left(12{ }^{\circ} \mathrm{C}\right)$ of the fjord during the experiment. Every day, half the volume of the water in the beakers was discarded and replaced by fresh fjord water taken from 35 $m$ depth (32-34 salinity). Disturbance of animals was avoided as much as possible. One group of the animals was fed with Artemia-nauplii (4 days old, $1 \mathrm{~mm}$ long). The nauplii were concentrated over $100 \mu \mathrm{m}$ gauze and then were added drop by drop with a pipette to the beakers with krill. The optimal number was 2000 to 3000 nauplii per animal and per day (Salomon, 2000). The second group was kept without food. At the end of the experiment (6d) the krill were quickly grasped with a forceps dorsally in the middle of the pleon, freeze clamped, wrapped in aluminium-foil and frozen and stored in liquid nitrogen.

\subsection{Tissue homogenization and purification of pyruvate kinase}

Individuals were weighed to an accuracy of $0.1 \mathrm{mg}$ and the sex was determined. Only animals in the intermoult stage were used. Organs and tissues were quickly dissected from frozen animals. Individuals (approx. 300 $\mathrm{mg}$ ) or organs and tissues (40-100 mg) were homogenized with an Ultra-Turrax (Janke and Kunkel) in 2.7 $\mathrm{ml}$ (entire animals) or $1.2 \mathrm{ml}$ (organ samples) of icecold extraction buffer $\left(50 \mathrm{mmol} \cdot 1^{-1}\right.$ Tris/ $\mathrm{HCl}, \mathrm{pH} 7$, including $60 \mathrm{mmol} \cdot 1^{-1} \mathrm{KCl}$ and $4 \mathrm{mmol} \cdot 1^{-1} \mathrm{MgSO}_{4}$ ). After centrifuging at $80,000 \times g$ for $30 \mathrm{~min}$ the supernatant was desalted and rebuffered into the elution buffer $\left(40 \mathrm{mmol} \cdot \mathrm{1}^{-1}\right.$ Tris/ $\mathrm{HCl}, \mathrm{pH} 8$, containing 4 $\mathrm{mmol} \cdot 1^{-1} \mathrm{KCl}$ and $\left.4 \mathrm{mmol} \cdot 1^{-1} \mathrm{MgSO}_{4}\right)$ through 
Sephadex G-25 PD-10 or NAP 10 columns (AP Biosciences). Thereafter, the sample was applied to an anion-exchange column (UNO Q1-R, Bio Rad). Bound proteins were eluted with a linear gradient between 0 and $250 \mathrm{mmol} \cdot 1^{-1} \mathrm{NaCl}$ at a flow rate of 2.5 $\mathrm{ml} \cdot \mathrm{min}^{-1}$ using a FPLC-system (AP Biosciences). Fractions $(0.5 \mathrm{ml}$ each $)$ containing at least $30 \%$ of the maximum PK-activity were pooled and used for further characterization.

The activity of PKI and PKII within different organs of $M$. norvegica was determined after ion-exchange chromatography. In order to obtain sufficient enzyme activity organs were pooled from several animals: eyes (4), gonads (4), hepatopancreas (4) and heart (8).

\subsection{Gel filtration}

The molecular weights of the two PK-isoenzymes were determined by gel filtration using a FPLC-system. The partly purified enzymes after anion exchange chromatography were applied onto a Superdex 200 HiLoad 16/60 column (AP Biosciences, 17-1069-01). The elution buffer was $0.01 \mathrm{~mol} \cdot 1^{-1}$ Imidazol/ $\mathrm{HCl}, \mathrm{pH} 6.8$ including $0.15 \mathrm{~mol} \cdot 1^{-1} \mathrm{NaCl}$. Molecular mass calibration was performed with a gel filtration calibration kit (AP Bioscience) containing: ribonuclease A (13.4 kDa), chymotrypsinogen A $(25 \mathrm{kDa})$, ovalbumin $(43 \mathrm{kDa})$, bovine serum albumin $(67 \mathrm{kDa})$, aldolase $(158 \mathrm{kDa})$, catalase $(232 \mathrm{kDa})$ and ferritin $(440 \mathrm{kDa})$.

\subsection{Enzyme characterization}

PK activity was measured according to Bücher and Pfleiderer (1955) at $25{ }^{\circ} \mathrm{C}$. Standard assays contained $500 \mu \mathrm{l}$ extraction buffer, $20 \mu \mathrm{l} \mathrm{NADH}\left(6900 \mu \mathrm{mol} \cdot 1^{-1}\right)$, $20 \mu \mathrm{l}$ phosphoenolpyruvate (PEP, $1800 \mu \mathrm{mol} \cdot \mathrm{l}^{-1}$ ), 5.5 units lactate dehydrogenase (LDH) and $20 \mu 1$ of the sample. The reaction was started after $5 \mathrm{~min}$ of preincubation by the addition of $20 \mu \mathrm{l}$ ADP (1700 $\left.\mu \mathrm{mol} \cdot 1^{-1}\right)$. The decrease of absorbance at $340 \mathrm{~nm}$ was recorded photometrically.

The thermal profile of PK was determined between 5 and $55{ }^{\circ} \mathrm{C}$. The activation energy $\left(E_{\mathrm{a}}\right)$ was calculated from the data between 5 and $25{ }^{\circ} \mathrm{C}$ by applying the Arrhenius equation.

The activities of PK isoenzymes were determined with the following effectors: ATP (167 and 2667 $\left.\mu \mathrm{mol} \cdot 1^{-1}\right)$, fructose-1,6-bisphosphate $\left(17 \mu \mathrm{mol} \cdot 1^{-1}\right)$, and citrate, lactate, Acetyl-CoA, fructose-6-phosphate, fructose-2,6-bisphosphate, glutamic acid, glutamine, leucine, D- and L-alanine, serine, valine, threonine, cysteine, and phenylalanine (each $250 \mu \mathrm{mol} \cdot \mathrm{l}^{-1}$ ).
The assays were run under standard condition and at half maximum substrate concentration $\left(33 \mu \mathrm{mol} \cdot 1^{-1}\right.$ PEP for PKI and PKII+ $200 \mu \mathrm{mol} \cdot 1^{-1} \mathrm{FBP}, 167$ $\mu \mathrm{mol} \cdot 1^{-1}$ PEP for PKII and $250 \mu \mathrm{mol} \cdot 1^{-1}$ ADP).

\section{6. $K_{m}$-values}

The $K_{\mathrm{m}}$-values of PK for PEP were calculated from reaction velocities at substrate concentrations from 3 to $670 \mu \mathrm{mol} \cdot 1^{-1}$. The concentration for ADP was kept constant at $570 \mu \mathrm{mol} \cdot 1^{-1}$. The $K_{\mathrm{m}}$-value for PKII was determined with and without FBP $\left(200 \mu \mathrm{mol} \cdot 1^{-1}\right) . K_{\mathrm{m}^{-}}$ values were calculated with the Graph Pad Prism software version 3.00 for Windows (GraphPad Software, San Diego, California, USA, www.graphpad.com).

\subsection{Protein determination}

Soluble proteins of extracts and eluents were measured according to Bradford (1976) using a commercial protein assay (Bio Rad, 500-0006). The assay was modified for the use in microplates. In brief, 20 to 50 $\mu 1$ of sample were applied into the wells of the microplate and water (a. dem.) was added to a volume of 50 $\mu \mathrm{l}$. Then $250 \mu \mathrm{l}$ of dye solution (diluted 1:5 with a. dem.) was added. After 15 min the plate was read at $600 \mathrm{~nm}$ in a microplate reader. Bovine serum albumine (BioRad 500-0007, 0 to $5 \mu \mathrm{g}$ per well) was used as a standard. On the same plate samples were applied in triplicate and standards in duplicate.

\subsection{Extraction and determination of Fructose-1.6- bisphosphate (FBP) and nucleotides}

Deep frozen animals were ground to a fine powder in a mortar which was cooled with liquid nitrogen. The frozen powder was transferred into $2 \mathrm{ml}$ of $0.5 \mathrm{~mol} \cdot 1^{-1}$ trichloroacetic acid. It was further processed with an Ultra-Turrax T25 (Janke und Kunkel) for $20 \mathrm{~s}$ and incubated on ice for $10 \mathrm{~min}$. After centrifugation at $4500 \times g$ for $10 \mathrm{~min}$ the supernatants were decanted and neutralized with trioctylamin and freon $(2 \mathrm{ml}$ trioc-

Table 1

Purification of pyruvate kinase from Meganyctiphanes norvegica

\begin{tabular}{llllll}
\hline $\begin{array}{l}\text { Purification } \\
\text { step }\end{array}$ & $\begin{array}{l}\text { Total } \\
\text { protein } \\
(\mathrm{mg})\end{array}$ & $\begin{array}{l}\text { Total } \\
\text { activity } \\
(\mathrm{U})\end{array}$ & $\begin{array}{l}\text { Specific } \\
\text { activity } \\
\left(\mathrm{U} \cdot \mathrm{mg}_{\mathrm{Pr}}^{-1}\right)\end{array}$ & $\begin{array}{l}\text { Purification } \\
\text { factor }\end{array}$ & $\begin{array}{l}\text { Yield } \\
(\%)\end{array}$ \\
\hline Crude extract & 8.0 & 11.5 & 1.4 & 1.0 & 100 \\
G25 & 7.7 & 10.1 & 1.3 & 0.9 & 90 \\
UNO Q1-R & 2.1 & 8.5 & 4.1 & 3 & 80 \\
Superdex 200 & 0.03 & 1.3 & 42 & 30 & 11.3 \\
\hline
\end{tabular}


Table 2

Temperature maximum, activation energy and molecular weight of $\mathrm{PKI}$ and PKII in Meganyctiphanes norvegica

\begin{tabular}{llll}
\hline Isoenzymes & $\begin{array}{l}\text { Temperature } \\
\text { maximum, } \\
(n=4)\end{array}$ & $\begin{array}{l}\text { Activation energy } \\
\left(E_{\mathrm{a}}\right), \mathrm{kJ} \cdot \mathrm{mol}^{-1} \\
(n=4)\end{array}$ & $\begin{array}{l}\text { Molecular } \\
\text { weight, } \mathrm{kDa} \\
(n=4)\end{array}$ \\
\hline PKI & $41.7 \pm 1.4$ & $53.7 \pm 4.2$ & $212.5 \pm 9.4$ \\
PKII & $45.0 \pm 2.5$ & $56.8 \pm 2.6$ & $235.5 \pm 4.7$ \\
\hline
\end{tabular}

Significant differences between PKI and PKII were present in all parameters (Student's $t$-test, $p<0.05$ ).

tylamin $94 \%+10 \mathrm{ml}$ freon). The aqueous phase was immediately used for FBP and nucleotide analysis. The concentration of FBP was determined as described by Michal (1984).

Nucleotides in the total body of krill were quantified by ion pair chromatography in reversed phase with a HPLC-system (Sykam, Gilching, Germany) modified after Moal et al. (1989) and Salomon (2000). Nucleotides were separated with a Phenomenex $5 \mu \mathrm{C} 18$ Luna-column $(4.6 \times 150 \mathrm{~mm})$ and a same pre-column cartridge (Phenomenex, USA). The mobile phase was a $\mathrm{NaH}_{2} \mathrm{PO}_{4}$-buffer $\left(0.2 \mathrm{~mol} \cdot \mathrm{l}^{-1} \mathrm{pH}\right.$ 6.0 ) containing $20 \%$ methanol and $5 \mathrm{mmol} \cdot \mathrm{l}^{-1}$ tetrabutylammonium as ion-pairing agent. The flow rate was $1 \mathrm{ml} \cdot \mathrm{min}^{-1}$. Nucleotides were detected at 254 $\mathrm{nm}$ with a UV-spectrophotometer. Nucleotide standards (Sigma) of 5, 25, 50, $100 \mu \mathrm{mol}$ were used for identification and peak quantification. The adenylate energy charge (AEC) was calculated after Atkinson (1977): $\mathrm{AEC}=(\mathrm{ATP}+\mathrm{ADP} / 2) /(\mathrm{ATP}+\mathrm{ADP}+\mathrm{AMP})$.

\subsection{Statistics}

Data sets were analysed for statistical differences with a $t$-test or an ANOVA followed by the StudentNewman-Keuls test. The influence of the factors nutrition and temperature on the concentrations of ATP and FBP and on the energy charge was tested with a two way ANOVA followed by a Tukey-test. Results are presented in tables and figures as means \pm standard deviation. Significant differences $(p<0.05)$ are indicated by asterisks.

\section{Results}

\subsection{Enzyme purification}

Two distinct peaks pyruvate kinase activity were separated in crude extracts of $M$. norvegica. The first enzyme (PKI) eluted at a $\mathrm{NaCl}$ concentration of 0.05 $\mathrm{mol} \cdot 1^{-1}$ and the second one (PKII) at $0.15 \mathrm{~mol} \cdot \mathrm{1}^{-1}$. The progress of purification was similar in both isoforms. PK was enriched 3-fold after anion exchange chromatography and 30-fold after gel filtration (Superdex 200). The final yield was $11.3 \%$ (Table 1).

\subsection{Molecular weight, temperature optimum and activation energy}

PKI had a lower molecular weight $(212.5 \mathrm{kDa})$ than PKII $(235.5 \mathrm{kDa})$. Furthermore, the temperature optimum and the activation energy of PKI were slightly but significantly lower than those of PKII (Table 2).

\section{3. $K_{m}$-values}

The effect of PEP on the activities of PKI, PKII and PKII with $200 \mu \mathrm{mol} \cdot 1^{-1}$ FBP was examined. The PEP saturation curves for PKI and PKII+FBP showed a strong increase in the reaction velocity when PEP concentration increased (Fig. 1). At higher substrate concentrations the curve asymptotically approached the maximum velocity $\left(V_{\max }\right)$. In contrast to this hyperbolic curve, the reaction velocity for PKII without the activator FBP was almost linear. The $K_{\mathrm{m}^{-}}$ values for PKI and PKII+FBP were 30 and 37

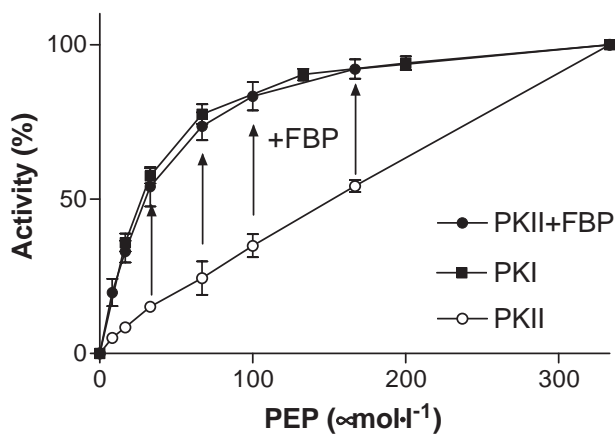

\begin{tabular}{lc}
\hline Isoenzyme & $\begin{array}{r}\mathrm{K}_{\mathrm{m}} \text {-value }^{\left(\mu \mathrm{mol} \cdot \mathrm{I}^{-1}\right)} \\
(\boldsymbol{3}\end{array}$ \\
\hline $\mathrm{PKI}$ & 30 \\
$\mathrm{PKII}$ & 1160 \\
$\mathrm{PKII}+\mathrm{FBP}$ & 37 \\
\hline
\end{tabular}

Fig. 1. The effect of PEP on the activities of PKI, PKII and PKII $+200 \mu \mathrm{mol} \cdot 1^{-1} \mathrm{FBP}$. The legend includes the $K_{\mathrm{m}}$-values calculated for PKI, PKII and PKII + FBP. 
$\mu \mathrm{mol} \cdot 1^{-1}$, respectively, and $1160 \mu \mathrm{mol} \cdot 1^{-1}$ for PKII. FBP had no effect on the kinetic of PKI (Salomon et al., 2000).

\subsection{Effectors}

The effects of different metabolites on the activity of PKI and PKII (PKII $\left.+200 \mu \mathrm{mol} \cdot 1^{-1} \mathrm{FBP}\right)$ were tested at half saturation concentration of the substrates PEP and ADP. ATP inhibited both isoenzymes slightly for $4-9 \%$ at a concentration of $170 \mu \mathrm{mol} \cdot 1^{-1}$ but significantly at a concentration of $2667 \mu \mathrm{mol} \cdot 1^{-1}$ (Table 3). The effect of ATP on the activity of PKII was the same regardless of the presence or absence of FBP. Slight activation appeared with F6P. Neither D- nor L-alanine showed distinct effects on the activities of both PK isoenzymes. This was also true for most other amino acids tested. Only cysteine and serine had a slightly enhancing effect on PKII.

\subsection{Specific activity and distribution of $P K$}

The weight-specific activity of PK in the total body of krill was higher in males than in females (61.3 $\mathrm{U} \cdot \mathrm{g}_{\mathrm{ww}}{ }^{-1}$ vs. $44.9 \mathrm{U} \cdot \mathrm{g}_{\mathrm{ww}}{ }^{-1}$, Table 4). Furthermore, in females the share of PKII of the total activity amounted to $20 \%$, while it was only $10 \%$ in males. The abdominal muscles had in both sexes the same ratio of PKI (90\%) and PKII (10\%). The specific activity in the muscles tissue of males was $50 \%$ higher than in females. Males had a higher amount of muscle tissue $(49.8 \pm 3.1 \%)$ than females $(46.2 \pm 1.6 \%)(t$ test, $p=0.004)$.

The highest enzyme activity was found in the heart and in the eyes followed by the pleopods and thoracopods. Low PK-activity was found in the stomach and the hepatopancreas. PKI was the dominant enzyme in the abdominal muscle, in the pleopods, the thoracopods and in the thoracic muscle tissue. PKII, in contrast, was dominant in the gonads, the eyes and in the midgut gland. In the heart PKII amounted to $40 \%$ of the total PK-activity. The protein specific PK-activities in the different organs showed a similar pattern as the weight specific activities. However, the protein related activity in the gonads was lower because of the high concentration of soluble protein $\left(80.6 \mathrm{mg} \cdot \mathrm{g}_{\mathrm{ww}}{ }^{-1}\right)$. The opposite was found in the stomach which had only 16.4 $\mathrm{mg} \cdot \mathrm{g}_{\mathrm{ww}}{ }^{-1}$ protein and, therefore, a high protein specific activity.

\subsection{Nucleotides in experimentally treated animals}

The concentrations of ATP ranged between 1.98 and $1.78 \mu \mathrm{g} \cdot \mathrm{mg}_{\mathrm{ww}}{ }^{-1}$. The values of AMP and ADP were used to calculate the AEC. The AEC was similar in all experimental groups amounting to about 0.97 (data not

Table 3

The effect of different metabolites on the activity of PKI, PKII and PKII \pm Fructose-1.6-bisphosphate $\left(200 \mu \mathrm{mol} \cdot 1^{-1}\right)$

\begin{tabular}{|c|c|c|c|c|}
\hline \multirow[t]{2}{*}{ Substance tested } & \multirow{2}{*}{$\begin{array}{l}\text { Concentration } \\
\left(\mu \mathrm{mol} \cdot 1^{-1}\right)\end{array}$} & \multicolumn{3}{|c|}{ Activity ( $\%$ of a control) } \\
\hline & & PKI & PKII & $\begin{array}{l}\text { PKII } \pm \text { Fructose-1.6-bis-phosphate } \\
\left(200 \mu \mathrm{mol} \cdot 1^{-1}\right)\end{array}$ \\
\hline \multirow[t]{2}{*}{ ATP } & 170 & $93.9 \pm 2.1^{*}$ & $91.3 \pm 11.6$ & $97 \pm 2.3^{*}$ \\
\hline & 2667 & $4.8 \pm 2.45^{*}$ & $27.8 \pm 22.1^{*}$ & $28.1 \pm 17.7^{*}$ \\
\hline Citrate & 250 & $96.7 \pm 3.6$ & $92.5 \pm 4.2^{*}$ & $92.5 \pm 18.2$ \\
\hline \multirow[t]{2}{*}{$\mathrm{ATP} \pm$ Citrate } & $170 \pm 250$ & $100.1 \pm 1$ & $88 \pm 3.2^{*}$ & $92.3 \pm 4.8^{*}$ \\
\hline & $2667 \pm 250$ & $7.6 \pm 3.5^{*}$ & $23.4 \pm 26^{*}$ & $16.9 \pm 10^{*}$ \\
\hline Lactate & 250 & $92.7 \pm 3.1^{*}$ & $101.6 \pm 6.5$ & $93.2 \pm 6.2^{*}$ \\
\hline Acetyl-CoA & 250 & $93.2 \pm 6.3^{*}$ & $86 \pm 4.8^{*}$ & $97.4 \pm 2 *$ \\
\hline Fructose-6-phosphate & 250 & $102.3 \pm 7.9$ & $113 \pm 12.2^{*}$ & $102.7 \pm 5$ \\
\hline Fructose-1.6-bisphosphate & 17 & $102.3 \pm 0.4^{*}$ & $229.3 \pm 48.8^{*}$ & \\
\hline Fructose-2.6-bisphosphate & 250 & $102.5 \pm 3$ & $99.6 \pm 2.5$ & \\
\hline Glutamic acid & 250 & $98.4 \pm 8.8$ & $108.9 \pm 13.5$ & \\
\hline Glutamine & 250 & $98.3 \pm 4.3$ & $104 \pm 9.1$ & \\
\hline Leucine & 250 & $95.8 \pm 2.6^{*}$ & $97.7 \pm 12.2$ & \\
\hline D-Alanine & 250 & $99.5 \pm 3.5$ & $101.4 \pm 6.4$ & \\
\hline L-Alanine & 250 & $98.2 \pm 6.8$ & $98.8 \pm 2.7$ & $95.6 \pm 3^{*}$ \\
\hline Serine & 250 & $102.3 \pm 4.7$ & $123.7 \pm 16.1 *$ & \\
\hline Valine & 250 & $96.1 \pm 1.5^{*}$ & $97.8 \pm 3.3$ & \\
\hline Threonine & 250 & $102 \pm 3.1$ & $106 \pm 13.8$ & \\
\hline Cysteine & 250 & $99.3 \pm 5.8$ & $125.5 \pm 9.4^{*}$ & \\
\hline Phenylalanine & 250 & $100.2 \pm 2.8$ & $102.6 \pm 2.8$ & \\
\hline
\end{tabular}

Values are given as percentage of the control $(100 \%) \pm$ S.D. Significant differences from the control are indicated by asterisks $(p<0.05)$. 
Table 4

Specific activity of the PK, wet weight (ww), soluble protein and the share of PKI and PKII in the total body and different organs of $M$. norvegica

\begin{tabular}{|c|c|c|c|c|c|c|c|}
\hline Organ & Sex & $\begin{array}{l}\text { Wet weight } \\
\text { (mg/organ) }\end{array}$ & $\begin{array}{l}\text { Specific activity } \\
\left(\mathrm{U} \cdot \mathrm{g}_{\mathrm{ww}}-1\right)\end{array}$ & $\begin{array}{l}\text { Protein } \\
\left(\mathrm{mg} \cdot \mathrm{g}_{\mathrm{ww}}{ }^{-1}\right)\end{array}$ & $\begin{array}{l}\text { Specific activity } \\
\left(\mathrm{U} \cdot \mathrm{mg}_{\mathrm{Pr}}^{-1}\right)\end{array}$ & $\begin{array}{l}\text { PKI ( } \% \text { of } \\
\text { total activity) }\end{array}$ & $\begin{array}{l}\text { PKII ( } \% \text { of } \\
\text { total activity) }\end{array}$ \\
\hline Total body $(n=22)$ & q & $249.8 \pm 47.9$ & $44.9 \pm 4.8$ & $38 \pm 3.3$ & $1.2 \pm 0.2$ & $79.5 \pm 3.3$ & $20.5 \pm 3.3$ \\
\hline Total body $(n=22)$ & $\widehat{0}$ & $215.7 \pm 42.7$ & $61.3 \pm 7.7$ & $32 \pm 3.6$ & $1.9 \pm 0.3$ & $89.2 \pm 2.5$ & $10.8 \pm 2.5$ \\
\hline Abdomen without pleopods $(n=10)$ & q & $102.9 \pm 10.5$ & $47.2 \pm 4.7$ & $35.6 \pm 3.7$ & $1.2 \pm 0.3$ & $89.3 \pm 4.2$ & $10.7 \pm 4.2$ \\
\hline Abdomen without pleopods $(n=10)$ & $\widehat{0}$ & $89.6 \pm 16.7$ & $74.1 \pm 16.5$ & $37.5 \pm 6$ & $2.1 \pm 0.9$ & $91.9 \pm 2.8$ & $8.1 \pm 2.8$ \\
\hline Pleopods and thoracopods $(n=3)$ & q & $24.6 \pm 2.3$ & $54.1 \pm 3.8$ & $35.5 \pm 2.3$ & $1.5 \pm 0.2$ & $86.9 \pm 3.3$ & $13.1 \pm 3.3$ \\
\hline Thoracic muscle $(n=3)$ & q & $33.1 \pm 5.6$ & $41.1 \pm 9.4$ & $47.2 \pm 4.8$ & $0.9 \pm 0.4$ & $73.6 \pm 8.5$ & $26.4 \pm 8.5$ \\
\hline $\begin{array}{l}\text { "Head" (eyes, antennules, antennas, } \\
\text { antennal scales, eye-sockets) }(n=3)\end{array}$ & q & $16.6 \pm 2.0$ & $51.9 \pm 8.6$ & $34.4 \pm 1.8$ & $1.5 \pm 0.5$ & $53.3 \pm 7.1$ & $46.5 \pm 7.1$ \\
\hline Eyes $(n=3)$ & q & $4.2 \pm 0.5$ & $59.4 \pm 8.8$ & $56.3 \pm 4.6$ & $1.1 \pm 0.1$ & $22.8 \pm 2.2$ & $77.2 \pm 2.2$ \\
\hline Midgut gland $(n=3)$ & q & $7.8 \pm 0.9$ & $16 \pm 9.8$ & $46.7 \pm 25.1$ & $0.3 \pm 0.05$ & $28.1 \pm 10.2$ & $71.9 \pm 10.2$ \\
\hline Stomach $(n=3)$ & q & $2.8 \pm 0.6$ & $17.1 \pm 7.7$ & $16.4 \pm 3.5$ & $1.1 \pm 0.5$ & $56.3 \pm 4.5$ & $43.7 \pm 4.5$ \\
\hline Heart $(n=3)$ & q & $1.4 \pm 0.3$ & $67.1 \pm 9.1$ & $54.6 \pm 12.5$ & $1.3 \pm 0.6$ & $60.1 \pm 3.9$ & $39.9 \pm 3.9$ \\
\hline Gonads $(n=3)$ & q & $12 \pm 4.4$ & $42 \pm 1.9$ & $80.6 \pm 2.7$ & $0.5 \pm 0.06$ & $5.1 \pm 3.4$ & $94.9 \pm 3.4$ \\
\hline
\end{tabular}

In routine, extracts were prepared from individual animals. If the amount of tissue was too small, samples were pooled to obtain sufficient material to analyse: eyes (4 ind.), gonads (4 ind.), hepatopancreas (4 ind.) and heart (8 ind.).

shown). Neither feeding condition nor the acclimation temperature significantly influenced the ATP content of the Northern krill.

\subsection{Fructose-1.6-bisphosphate in experimentally treated animals}

Both factors, temperature and nutrition, significantly influenced the FBP-concentrations in $M$. norvegica (Fig. 2). The highest amount of $6.8 \mu \mathrm{g} \cdot \mathrm{g}_{\mathrm{ww}}{ }^{-1}$ was present in fed animals which were maintained at 12 ${ }^{\circ} \mathrm{C}$. In starved animals the amount of FBP was about $30 \%$ lower then in fed animals. The same differences appeared in krill maintained at $6{ }^{\circ} \mathrm{C}$. FBP-levels of cold acclimated animals were $35 \%$ lower then in warm acclimated specimens. Therefore, the lowest FBP con-

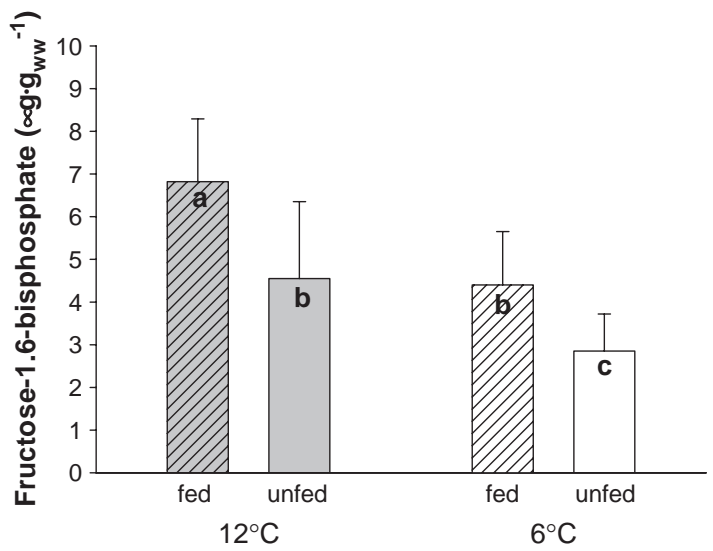

Fig. 2. Concentrations of FBP in whole body extracts of $M$. norvegica maintained at 6 and $12{ }^{\circ} \mathrm{C}$ with and without feeding. Different letters denote significant differences between treatments $(p<0.05, n=8)$. centration of $2.85 \mu \mathrm{g} \cdot \mathrm{g}_{\mathrm{ww}}{ }^{-1}$ appeared in unfed krill maintained at $6{ }^{\circ} \mathrm{C}$.

\section{Discussion}

The Northern krill, M. norvegica, expressed two isoforms of pyruvate kinase, PKI and PKII. Both isoforms differed distinctly in terms of chromatographic properties, thermal characteristics, activation energy and molecular masses (Salomon et al., 2000). PKI had a low $K_{\mathrm{m}}$-value and thus a high affinity towards the substrate PEP. It was not affected by modulators. In contrast, PKII had a low affinity towards PEP. The glycolytic key metabolite FBP, however, strongly increased the affinity of PKII towards PEP. The $K_{\mathrm{m}^{-}}$ values decreased up to 40 -fold when FBP was present. In contrast, none of the tested amino acids including Dand L-alanine had significant effects on the activity of PKI and PKII. The lack of regulative potential of alanine was already reported for M. norvegica from the Ligurian Sea. This property was attributed to the poor anaerobic capacity of Northern krill (Spicer et al., 1999; Salomon et al., 2000). ATP inhibited both isoenzymes at high concentrations.

\subsection{Organ and tissue specificity}

All studied organs and tissues of $M$. norvegica contained both PK isoenzymes. However, the share of either enzyme differed strongly between the tissues and showed a distinct pattern of distribution: PKI was the predominant form in the muscles of the locomotive organs, i.e. the abdominal muscle, the pleopods, and the thoracopods. These organs also exhibited a high 
specific PK-activity. It is vital for the pelagic krill to provide energy for locomotion to counteract sinking. Accordingly, it turns out plausible that PKI, the isoenzyme with the high substrate affinity, is the dominating form in the muscle tissue. In contrast, the highest share of PKII appeared in the midgut gland. This is in accordance with previous studies on several crustacean species: a PK, comparable with the mammalian L-type PK and the same properties as the PKII was found in the midgut gland of different crustaceans (Giles et al., 1977; Guderley and Hochachka, 1977; Lesicki, 1983). Additionally, PKII was the dominating isoform in the eyes and in the gonads. In the latter almost the entire PK-activity appeared as PKII. Accordingly, the glycolytic turnover in the midgut gland, the eyes and the gonads highly depends on the concentration of the activator FBP.

The FBP concentration in the tissue is correlated with the nutritional state of the animal (Pilkis et al., 1988). At limiting conditions the concentration of FBP decrease, which entails a reduction of the glycolytic energy transfer. In the gonads, energy and metabolites are mainly provided for gonad growth and maturation. Northern krill can only successfully reproduce at sufficient food supply (Cuzin-Roudy, 1993; Cuzin-Roudy and Buchholz, 1999). Accordingly, the dominance of FBP-activated PKII may be a suitable physiological mechanism to direct energy and metabolites into the gonads only when sufficient food is available.

The eyes which showed the highest specific PK activity are energy demanding organs (Demontis et al., 1997; Laughlin et al., 1998). Although metabolic costs of vision in the Northern krill are not well known yet, the energetic demand can be expected high. Due to the elevated share of PKII, a decrease in FBP-level may entail reduced glycolytic turnover rates. Thus, a reduction of glycolytic rates again may be a tool to save energy at limited nutritive conditions.

In the midgut gland the majority of metabolic processes are directly linked with food utilization. A high glycolytic turnover rate is needed particularly for synthesis of digestive enzyme and transfer processes. On starvation crustaceans reduce the size of the midgut gland and metabolize storage products such as lipids and glycogen (Strus, 1987; Papathanassiou and King, 1984). Furthermore, digestive enzyme activities decrease on starvation (Saborowski and Buchholz, 1999). The regulative potential of PKII in the midgut gland seems to be a suitable mechanism to control the glycolytic energy transfer.

The total PK-activities in the whole animals and the abdominal muscle were significantly higher in males than in females. However, males showed in the whole body $50 \%$ less PKII-activity than females. The testes are much smaller than the ovaries especially during the reproductive season (Bargmann, 1937; Albessard et al., 2001). Furthermore, the abdominal muscle was slightly larger in males than in females. Consequently, the share of PKI-rich tissue is higher in males.

\subsection{Food supply and temperature}

We studied the effects of nutrition and temperature on PK-kinetics by altering the levels of the major effectors ATP and FBP. In laboratory experiments $M$. norvegica were exposed for 6 days to two different feeding and thermal conditions. ATP, ADP and AMP concentrations were used to calculate the adenylate energy charge (AEC) (Atkinson, 1977). An AEC value close to 1 reflects a high amount of ATP compared to ADP and AMP. Vetter and Hodson (1982) investigated several fish species and established a "normal" value for a viable organism close to 0.9 . The energy charge values published by other authors for M. norvegica are lower than our data. Skjoldal and Båmstedt (1976) established a maximum value of 0.76 and Saether and Mohr (1987) of 0.65. These data were gained from animals which were frozen directly after capture. These krill had most likely depleted ATP stores due to capture stress and enforced swimming. The high energy charge of 0.97 measured in our study indicates that the animals were not stressed and the handling before freezing the krill was suitable to avoid significant ATP degradation.

The ATP levels are in the same range as reported for other crustaceans (Dehn et al., 1985; Onnen and Zebe, 1983; Dickson and Giesy, 1982; Harms et al., 1990). However, studies on the influence of nutrition on ATP levels gave contradictory results, e.g. Dickson and Giesy (1982) found an increase of the ATP in the crayfish Procambarus clarkii and a decrease in the crayfish Orconectes inermis after some days of starvation. The ATP levels in Northern Krill were neither influenced by the feeding conditions of the animals nor by the temperature. Skjoldal and Båmstedt (1976) found in M. norvegica from the Norwegian Korsfjorden elevated ATP and adenine nucleotides levels in March and April than during the rest of the year. The authors suggested that this increase is the result of an inherent physiological rhythm associated more with the reproduction cycle than with changes in the food supply. Accordingly, it seems unlikely that pyruvate kinase is regulated by external factors via changes in the concentrations of the modulator ATP. 
FBP is an activator of PKII. In $M$. norvegica the levels of FBP varied between 2.9 and $6.8 \mu \mathrm{g} \cdot \mathrm{g}_{\mathrm{ww}}-1$. In comparison, Beis and Newsholme (1975) determined FBP-concentrations from 6.8 to $81.6 \mu \mathrm{g} \cdot \mathrm{g}_{\mathrm{ww}}{ }^{-1}$ in the flight muscles of insects and a FBP-concentration of $37.4 \mu \mathrm{g} \cdot \mathrm{g}_{\mathrm{ww}}{ }^{-1}$ in the abdominal muscle of the lobster Homarus vulgaris.

Food limitation and low temperatures caused a decrease in the FBP concentration in Krill. Animals which starved for 6 days showed 30\% lower FBPconcentrations at both experimental temperatures. A similar reduction of FBP in the livers of rats after 10 $\mathrm{h}$ of food deprivation was reported by Chanez et al. (1988). The temperature also strongly influenced the FBP-levels in krill. The values for cold acclimated animals were $30 \%$ lower then those of warm acclimated ones. The decrease of FBP is correlated with the metabolic reduction at low temperatures as measured by respiration rates of krill (Saborowski et al., 2002). Accordingly, both factors influence PKII in Northern krill through the variation of FBP concentrations.

\section{Conclusion}

M. norvegica showed two PK-isoenzymes, an "active PK P" and "inactive PK II" one. The latter one was activated by FBP, a key metabolite of the glycolysic pathway. The concentration of FBP was highly dependent on nutrition and temperature. As a consequence of food deprivation or decreased temperature the glycolytic energy turnover may be reduced in some organs such as the gonads and the midgut gland. Simultaneously, the locomotive organs maintain high glycolytic turnover rates due to the presence of the "active" PK-isoform. The tissue specific distribution of the two different PK-isoenzymes seems to improve the krills physiological flexibility to successfully cope with low temperatures or limited food supply.

\section{Acknowledgements}

We wish to thank the crew of the research vessel "FS Heincke" for their assistance in the sampling programme as well as the members of the Kristinebergs Marina Forskningsstation (Sweden) for their kind help including financial support by the EUlarge Scale Facility. The support of F. Buchholz during this study is gratefully appreciated. This work was funded by an EU-MAST III fellowship to the first author (MAS3-CT96-5023). [SS]

\section{References}

Albessard, E., Mayzaud, P., Cuzin-Roudy, J., 2001. Variation of lipid classes among organs of the Northern krill, Meganyctiphanes norvegica, with respect to reproduction. Comp. Biochem. Physiol. 129A, 373-390.

Atkinson, D.E., 1977. Cellular Energy Metabolism and its Regulation. Academic Press, Inc., New York. 292 pp.

Bargmann, H.E., 1937. The reproductive system of Euphausia superba. Discov. Rep. 14, 325-350.

Beis, I., Newsholme, E.A., 1975. The contents of adenine nucleotides, phosphagens and some glycolytic intermediates in resting muscles from vertebrates and invertebrates. Biochem. J. 152, 23-32.

Bonamusa, L., García de Frutos, P., Fernandez, F., Baanante, I.V., 1992. Nutritional effects on key glycolytic-gluconeogenic enzyme activities and metabolite levels in the liver of the teleost fish Sparus aurata. Mol. Mar. Biol. Biotechnol. $1,113-125$.

Bradford, M.M., 1976. A rapid and sensitive method for the quantitation of microgram quantities of protein utilizing the principle of protein-dye binding. Anal. Biochem. 72, 248-254.

Bücher, T., Pfleiderer, G., 1955. Pyruvate kinase from muscle. In: Colowick, S., Kaplan, N.O. (Eds.), Methods in Enzymology, vol. I. Academic Press, New York, pp. 435-440.

Chanez, M., Bois-Joyeux, B., Peret, J., 1988. Age-dependent changes in rat hepatic fructose 2,6-bisphosphate, 6-phophofructo-2-kinase/ fructose 2,6-bisphosphatase and pyruvate kinase activity in response to a high protein diet or starvation. Diabete Metab. 14, $80-87$.

Cuzin-Roudy, J., 1993. Reproductive strategies of the Mediterranean krill, Meganyctiphanes norvegica and the Antarctic krill, Euphausia superba (Crustacea: Euphausiacea). Invertebr. Reprod. Dev. 23, 105-114.

Cuzin-Roudy, J., Buchholz, F., 1999. Ovarian development and spawning in relation to the moult cycle in Northern krill, Meganyctiphanes norvegica (Crustacea: Euphausiacea), along a climatic gradient. Mar. Biol. 133, 267-281.

Dehn, P.F., Haya, K., Aiken, D.E., 1985. Adenylate energy charge, arginine phosphate and ATPase activity in juvenile Homarus americanus during the molt cycle. Comp. Biochem. Physiol. $81 \mathrm{~B}, 629-633$.

Demontis, G.C., Longoni, B., Gargini, C., Cervetto, L., 1997. The energetic cost of photoreception in retinal rods of mammals. Arch. Ital. Biol. 135, 95-106.

Dickson, G.W., Giesy, J.P., 1982. The effects of starvation on muscle phosphoadenylate concentrations and adenylate energy charge of surface and cave crayfish. Comp. Biochem. Physiol. 71A, 357-361.

Einarsson, H., 1945. Euphausiacea. 1. North Atlantic Species, Dana Rep., vol. 27. 185 pp.

Giles, I.G., Poat, P.C., Munday, K.A., 1977. An investigation of the interactions of the allosteric modifiers of pyruvate kinase with the enzyme from Carcinus maenas hepatopancreas. Biochem. J. 165, 97-105.

Guderley, H., Hochachka, P.W., 1977. Gluconeogenic control adaptations in Cancer magister: hypodermal pyruvate kinase, an enzyme with high- and low affinity states. Arch. Biochem. Biophys. 182, $465-477$.

Harms, J., Moal, J., Le Coz, J.R., Daniel, J.Y., Samain, J.F., 1990. Nucleotide composition and energy charge in growing and starving zoea I of Carcinus maenas (Decapoda: Portunidae). Comp. Biochem. Physiol. 96B, 405-414. 
Imamura, K., Tanaka, T., 1972. Multimolecular forms of pyruvate kinase from rat and other mammalian tissues: I. Electrophoretic studies. J. Biochem. (Tokyo) 71, 1043-1051.

Imamura, K., Taniuchi, K., Tanaka, T., 1972. Multimolecular forms of pyruvate kinase. II. Purification of $\mathrm{M}_{2}$-type pyruvate kinase from Yoshida ascites hepatoma 130 cells and comparative studies on the enzymological and immunological properties of the three types of pyruvate kinase L, M and $\mathrm{M}_{2}$. J. Biochem. (Tokyo) 72, $1001-1015$.

Isaacs, J.D., Kidd, L.W., 1953. Isaacs-Kidd mid-water trawl. Scripps Inst. Oceanogr. 18 (Ref. 53).

Kils, U., 1981. Swimming behaviour, swimming performance and energy balance of Antarctic krill Euphausia superba. BIOMASS Sci. Ser. 3 (121 pp.).

Laughlin, S.B., De Ruyter van Steveninck, R.R., Anderson, J.C., 1998. The metabolic cost of neural information. Nat. Neurosci. $1,36-41$.

Lazou, A., Frosinis, A., 1994. Kinetic and regulatory properties of pyruvate kinase from Artemia embryos during incubation under aerobic and anoxic conditions. The effect of $\mathrm{pH}$ on the kinetic constants. Comp. Biochem. Physiol. 109B, 325-332.

Lesicki, A., 1976. Characteristic of isoenzymes of pyruvate kinase isolated from some crayfish Orconectes limosus RAF. (Crustacea: Decapoda) tissues. Comp. Biochem. Physiol. 55B, 273-277.

Lesicki, A., 1983. Electrophoretic studies on pyruvate kinase from the hepatopancreas of the crayfish, Orconectes limosus R A F. (Crustacea, Decapoda). Bull. Soc. Amis Sci. Lett. Pozn., Ser. D 23, 5-10.

Lindley, J.A., 1982. Population dynamics and production of Euphausiids. III. Meganyctiphanes norvegica and Nyctiphanes couchii in the North Atlantic and the North Sea. Mar. Biol. 66, 27-46.

Mauchline, J., 1960. The biology of euphausiid crustacean, Meganyctiphanes norvegica (M. Sars). Proc. Zool. Soc. Edinburgh, B 67, 141-179.

Mauchline, J., Fischer, L.R., 1969. The biology of euphausiids. Adv. Mar. Biol. 7, 1-454.

Michaelidis, B., Storey, K.B., 1990. Influence of $\mathrm{pH}$ on the regulatory properties of aerobic and anoxic forms of pyruvate kinase in a marine whelk. J. Exp. Zool. 253, 245-251.

Michal, G., 1984. D-fructose 1,6-bisphosphate, dihydroxyacetone phosphate and D-glyceraldehyde 3-phosphate. In: Bergmeyer, H.U., Graßl, M. (Eds.), Methods of Enzymatic Analyses. VCH Verlagsgesellschaft, Weinheim, pp. 342-350.

Moal, J., Le Coz, J.R., Samain, J.F., Daniel, J.Y., 1989. Nucleotides in bivalves: extraction and analysis by high-performance liquid chromatography (HPLC). Comp. Biochem. Physiol. 93B, 307-316.

Oeschger, R., Storey, K.B., 1990. Regulation of glycolytic enzymes in the marine invertebrate Halicryptus spinulosus (Priapulida) during environmental anoxia and exposure to hydrogen sulfide. Mar. Biol. 106, 261-266.
Onnen, T., Zebe, E., 1983. Energy metabolism in the tail muscles of the shrimp Crangon crangon during work and subsequent recovery. Comp. Biochem. Physiol. 34A, 833-838.

Papathanassiou, E., King, P.E., 1984. Effects of starvation on the fine structure of the hepatopancreas in the common prawn Palaemon serratus (Pennant). Comp. Biochem. Physiol. 77A, 243-249.

Pilkis, S.J., El-Maghrabi, M.R., Claus, T.H., 1988. Hormonal regulation of hepatic gluconeogenesis and glycolysis. Ann. Rev. Biochem. 57, 755-783.

Saborowski, R., Buchholz, F., 1999. A laboratory study on digestive processes in the Antarctic krill, Euphausia superba, with special regard to chitinolytic enzymes. Polar Biol. 21, 295-304.

Saborowski, R., Bröhl, S., Tarling, G.A., Buchholz, F., 2002. Metabolic properties of Northern krill, Meganyctiphanes norvegica, from different climatic zones: I. Respiration and excretion. Mar. Biol. 140, 547-556.

Saether, O., Mohr, V., 1987. Chemical composition of North Atlantic krill. Comp. Biochem. Physiol. 88B, 157-164.

Salomon, M., 2000. Einfluß der Ernährung und der Temperatur auf die Pyruvat-Kinase des Nordischen Krills, Meganyctiphanes norvegica (M. Sars, 1857). Doctoral thesis, University of Hamburg, Germany. 98 pp.

Salomon, M., Mayzaud, P., Buchholz, F., 2000. Studies on metabolic properties in the Northern Krill, Meganyctiphanes norvegica (Crustacea, Euphausiacea): influence of nutrition and season on pyruvate kinase. Comp. Biochem. Physiol. 127A, 505-514.

Skjoldal, H.R., Båmstedt, U., 1976. Studies on the deep-water pelagic community of Korsfjorden, Western Norway. Adenosine phosphates and nucleic acids in Meganyctiphanes norvegica (Euphausiacea) in relation to the life cycle. Sarsia 61, 1-14.

Spicer, J.I., Thomasson, M.A., Strömberg, J.-O., 1999. Possessing a poor anaerobic capacity does not prevent the diel vertical migration of Nordic krill Meganyctiphanes norvegica into hypoxic waters. Mar. Ecol. Prog. Ser. 185, 181-187.

Strus, J., 1987. The effects of starvation on the structure and function of the hepatopancreas in the isopod Ligia italica. Sci. Mar. 51, 505-514.

Tarling, G.A., Matthews, J.B.L., Saborowski, R., Buchholz, F., 1998. Vertical migratory behaviour of the euphausiid, Meganyctiphanes norvegica, and its dispersion in the Kattegat Channel. Hydrobiologia 375/376, 331-341.

Vetter, R.D., Hodson, R.E., 1982. Use of adenylate concentrations and adenylate energy charge as indicators of hypoxic stress in estuarine fish. Can. J. Fish. Aquat. Sci. 39, 535-541.

Wiebe, P.H., Morton, A.W., Bradley, A.M., Backus, R.H., Craddock, J.E., Barber, V., Cowles, T.J., Flierl, G.R., 1985. New developments in the MOCNESS, an apparatus for sampling zooplankton and micronekton. Mar. Biol. 87, 313-323. 